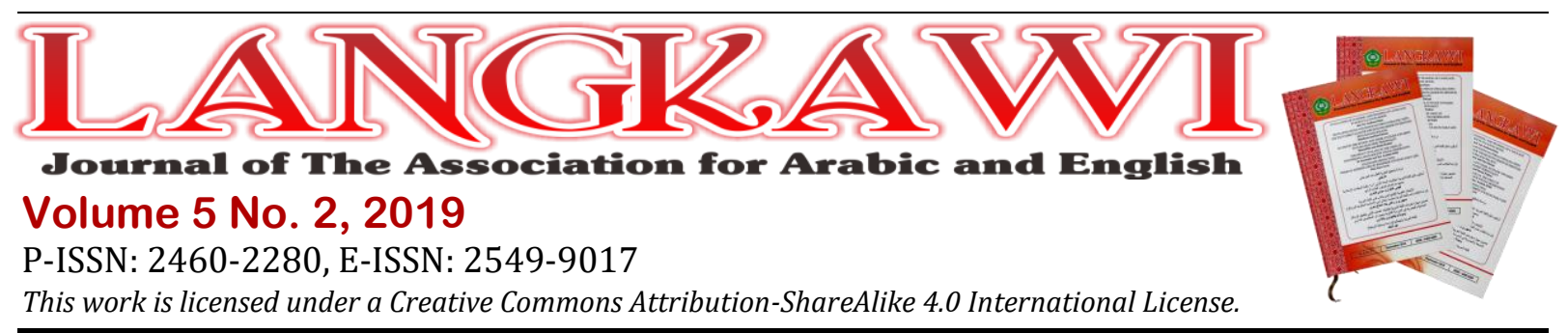

\title{
Riak in Dayak Maanyan Ritual Tradition (An Ethnolinguistics Study)
}

\author{
Dwiani Septiana1, Riyadi Santosa ${ }^{2}$, Sumarlam Sumarlam ${ }^{3}$ \\ ${ }^{1}$ Balai Bahasa Kalimantan Tengah,Palangka Raya, Indonesia. E-mail: dwiani.septiana@kemdikbud.go.id \\ 2 Universitas Sebelas Maret, Surakarta, Indonesia. E-mail: riyadisantosa@staff.uns.ac.id \\ ${ }^{3}$ Universitas Sebelas Maret, Surakarta, Indonesia. E-mail: sumarlam@staff.uns.ac.id
}

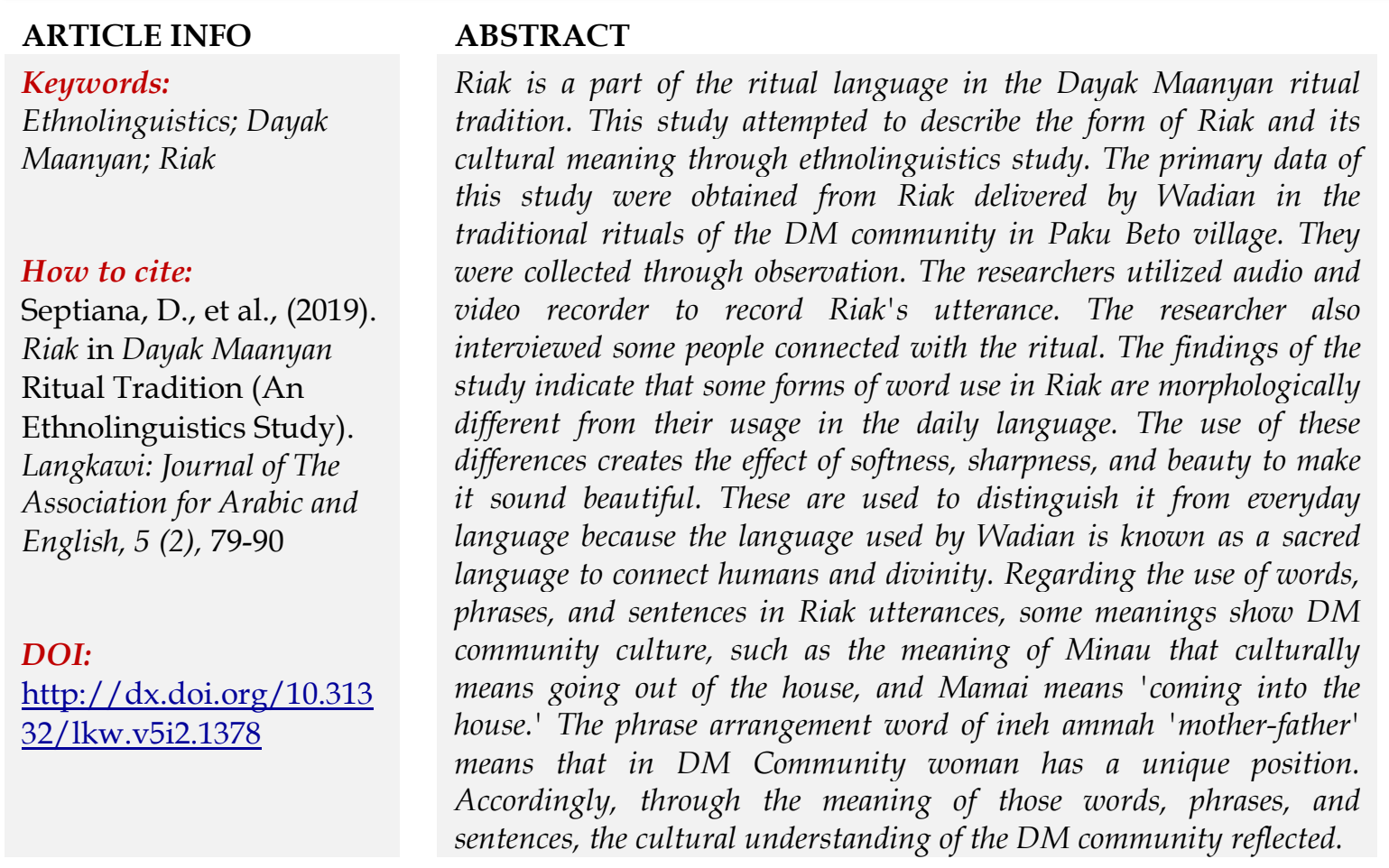

\section{Introduction}

The Dayak Maanyan (DM) lives in the interior, in the southern part of the central Kalimantan province. According to Eberhard et al. (2019) and Soriente (2012), DM people are mostly located in the Barito river basin, in the area of South Barito district and East Barito, to areas bordering and entering the province of South Kalimantan, Indonesia. The language they use is called the Maanyan language. The ancient DM community informed all activities that they would do to the village with Riak. Riak is a call for notification. Along with the time, some types of Riak have never been used again, such as Riak for facing a war, Riak for signifying danger, and Riak for notifying the community. Riak that still exists to this day is Riak in ritual, functioning as a notification about stages of the ritual that are being and will be conducted by the master of the ritual.

Riak is executed by a master or person considered as a community figure. In the context of traditional rituals, Riak is executed by a ritual master, known as Wadian. Ukur (1971) finds Wadian as a mediator between humans and the highest divinity, and principal director in all rituals in connection to the deity. The deity in the DM community may relate to the spirit of their ancestors. Besides a traditional 
and religious master, Wadian also plays as a healer or physician. Her ability to heal and to overcome various problems related to diseases is obtained through her communication with the spirit of her ancestors. These spirits show the way or sign for the healing process. In rituals conducted by Wadian, Riak exists, functioning as a notification of the ritual stages for the community who attend the ritual.

In the DM community, Riak can be categorized as a ritual language. Wheelock (1982) stated that ritual language is intimately and intrinsically connected with the action context of a ritual and used in accomplishing the ends of the ritual operation. Blust (2015) categorizes ritual language as an ancient language. He called James J. Fox the person who did the most research on ritual language, especially in languages in eastern Indonesia. According to Blust, Fox (2014) has succeeded in describing unique characteristics in ritual language, namely canonical parallelism. These characteristics are also obtained in the Chol Maya ritual language, which is characterized by the use of repetition forms, semantic, and syntactic parallelism (Rodriguez and Lopez 2019). Riak also has a form like that found by Blust in eastern Indonesia and Rodriguez and Lopez in the Chol Maya language.

Some studies related to ritual languages in Central Kalimantan that have been carried out before including research conducted by Mage (2014) on the use of ritual language in traditional marriage ceremonies, especially in the section he calls Patatiba, the second stage in the traditional ritual. At the beginning of the article, Mage provided a reasonably clear description of the ritual language in the DM language known as Pangunraun. In this article, Mage does not explain the ethnopoetics analysis, as mentioned in the research title, and the method used in collecting and analyzing research data is also not mentioned. So this article is just like documentation about ritual language in the DM community. There is also research on rituals in the Central Kalimantan region conducted by Herrmans $(2015,2017)$, in the southeastern Barito River region, in the residential areas of speakers of the Luangan language. A language related to the DM language (Sumadi et al., 2015). She used the approach from Dell Hymes to Turner to explored the ritual tradition in Luangan and showed it in situational ethnography. She also accommodated Belian invocation, song, and mythical narrative - all of those transcribed and nicely translated into English and added a more explicit description of the ritual practices. However, she did not explore Luangan cognitive experience and culture through those ritual and language used in that.

Exploring the cognitive experience and culture in language can be conducted in ethnolinguistics studies. Ethnolinguistic is derived from ethnography and linguistics. According to Heller in Copland and Creese (2015), ethnographic linguistics enables humans to see how language relates to the real condition of human life, to find out how and why languages are essential in human beings, and to see how its process is executed from time to time. Ethnography may also tell about an experience resulting in an explanation of why humans do and think of what they do. Ethnographic linguistics is often connected to anthropological linguistics. Duranti (1997) suggested that what he considers as anthropological linguistics also refers to ethnolinguistics, the more general term used in Europe. However, he implies a contrast between anthropological linguistics and linguistic anthropology. But according to Foley (2016), the two terms as interchangeable. 
Furthermore, Foley (2016) explained that anthropological linguistics regards a language through the prism of the main concept of anthropology, culture, and thus, attempts to reveal the meaning behind using or misusing the language, its different forms, registers, and styles. Moreover, Sharifian (2014) claimed that the study on anthropological linguistics focuses on documentation, description, and clarification of languages of the native community by considering languages as lexicon and grammar. Therefore, ethnolinguistics often related to anthropological linguistics is a sub-linguistics that not only describes the language with lexicon and grammar but also considers it as a cultural source, by taking account to its usage in the sociocultural context in the community.

Ethnolinguistics can be examined under macro-linguistics and microlinguistics. According to Rais (2017), an ethnolinguistic study in terms of macrolinguistics was conducted to know the language in the cultural context, to find out and to investigate the meaning behind using language, to get cultural understanding, which starts from language facts. Moreover, Wardhaugh and Fuller (2015) view the interconnection of language and culture in terms of their roles that influence each other. In term of ritual language, Riak has two first lines that illustrate the natural and social condition or environment where the DM community lives, and two following lines that indicate the purpose being conducted by Wadian in the ritual. Linguistic expression in Riak is refreshing to be analyzed to find out the meaning behind those expressions and to understand cultural values and views of the DM community and their surroundings, and also the local wisdom in the DM community. Besides, this study is expected to be able to reveal the cultural dynamism and habit of today's DM community in East Barito district, Central Kalimantan Province.

Based on micro-linguistics, the ethnolinguistic study considers linguistic forms, such as vocabularies, phrases, sentence structures, sentence forms, and registers (Rais, 2017). The linguistics form is one of the most used terms in linguistics. Crystal (2008) stated that one usage of the form in the linguistic context refers to phonological, grammatical, or lexical characteristics from linguistic units, such as sentences, morphemes, lexemes, and nouns. According to Saville-Troike (2003), the form of language used in the ritual context usually has specific characteristics. Those characteristics, such as, more conservative forms, lexical form such as the use of different predicate or the use of words with unique meaning, a morphological form that often involves different types, paralinguistics, kinesthetic, different communication tools such as bones, shells, horns, gendering, and receptor sense in trance state. Riak has those characteristics stated by Saville-Troike (2003); it has a specific morphological form that different from DM language that used daily, and it also has a unique word choice that reflects DM culture.

Refer to the things mentioned above; this study will discuss some problems, including (1) how the form of Riak in the DM community in East Barito district is, and (2) how the local culture of the DM community in East Barito district reflected in the language use of riak is. It aims to describe the form of riak in the DM community and local culture of the DM community in East Barito district reflected in riak. 


\section{Method}

This study used ethnography research methods. Based on linguistics, SavilleTroike (2003) suggested that ethnography is a field study that is concerned primarily with the description and analysis of culture, and linguistics is a field concerned, among other things, with the description and analysis of language codes. It indicates that ethnography is field research, particularly relating to the description and analysis of culture and linguistic codes. In conducting ethnography research, the field research in terms of observation, asking the question, participation in group activities, and checking the validity of human perception with native speaker's intuition had to be conducted.

The primary data of this study were obtained from riak delivered by wadian in the traditional wedding rituals of the DM community in Paku Beto village, Paku subdistrict, East Barito district, Central Kalimantan province. They were collected through observation and interview. The observation was conducted to obtain the primary data in terms of riak utterances in the traditional wedding ritual of the DM community. Using participant observation, the researcher observed the ongoing social life in the DM community and also participated in the traditional wedding ritual. Along the process, Riak utterance was recorded using audio and video recorder, and the researcher also made some notes of what was observed. As mention by Foley (2016) from these notes and observations, the researcher will gradually discern recurring patterns, and these will allow the researcher to generate hypotheses about what the various linguistic behaviors that have observed mean. The interview was also carried out concerning collecting the primary data because, according to Foley (2016), participant observation on its own cannot answer the questions about meanings. For that, the testimonies of native actors are needed. The interview was conducted in two ways, constructed interviews and open interviews. Constructed interviews are interviews with questions that focus on specific or general topics, for example, the context of Riak or how to chant, and what is the meaning of the words stated in Riak. Instead, an open interview is an interview by giving freedom to the informants and encouraging him to talk broadly and deeply related to the object of this study. The researcher interviewed the Wadian and two elders who understand about custom and law in the traditional wedding rituals in the DM community.

The data analysis started with translating Riak utterances. In the translation process, the researcher had the informant's help in translating the meaning of Riak utterance word by word and in sentences. The data analysis of this research departs from the analysis of language and then culture by examining the cultural content that exists in linguistic classes (Suhandano, 2004; Gunawan, 2005) The data then analyzed to lead to the discovery of a particular cultural meaning system through interpretation and inference. The data collected was analyzed in several stages, literal and contextual translation, analysis of linguistic unit forms, analyzing the culture of the DM community reflected in Riak, and making general conclusions related to the study. 


\section{Findings and Discussion}

Analysis of language and culture in riak will be divided into two parts; the first part is an analysis of linguistic forms in riak and its meanings and the second part about culture in riak

\subsection{The forms of Riak}

The form of Riak is similar to pantun; as stated by Riswara (2012), pantun is traditional poetry with the lyrics in each verse has a similarity sound at the end. Each Riak mostly consists of four lines, in which the first two lines (stanza) aim to prepare rhyme and rhythm to ease audiences understanding them while the second two lines are the purpose or content of Riak. There is no connection between the meaning of two first stanza and two final ones; they are only related in terms of sound to add Riak attractiveness. The exciting thing about the Riak is that the two first stanzas, in the beginning, are an illustration of the natural or environmental conditions in which the DM community lives, then followed by two final stanzas that reveal the purpose of the Wadian in the ceremony.

\section{Iya itaréték rawen angang Inyampuran ku rawen téwu Awat palu naun sa agung gandrang Kami ngalap pangantén upu}

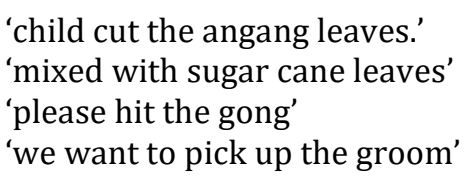

This Riak usually found in the DM wedding ceremony. It is delivered or used as a notification to the guests present about the next stages of Wadian, so before they do an activity in the dance, they will inform the guests in advance through Riak.

Along with the development and cultural dynamics among the DM community today, the riak that exist in traditional ceremonies, as well as notices about the next stage, also serve as entertainment for the people present at the ceremony. Riak can be sung spontaneously but can also be prepared and studied first, depending on the wadian or the situation. Due to its spontaneously, sometimes riak is not only using DM language, but there are also Indonesian, and Banjarese language. This language mixing with Banjarese in riak now could happen because of the DM community live in the border area, where the Bajarese live (Arini, 2016), so there must be a language contact between them.

In Riak, there are morphologically different uses of words in the daily language of the DM community, as Saville-Troike (2003) stated that the form of language used in the ritual context usually has specific characteristics, such as the use of different morphological form. There are three forms of word use with specific morphological characteristics, namely verb form with affix $i-$, clitics form $-n i$, and particle form use of $-s a$.

Affix $i$ - from data (1) to (7) below shows morphologically different use of verbs in the daily DM language. The $-i$ affix in the daily DM language, can join with nouns to form nouns, verbs. It forms an active and passive verb when joining a verb, and when joining the noun will have or become as stated by its base form. For example,

$$
\begin{aligned}
& i-+ \text { wure 'foam' } \rightarrow \text { iwure 'foamy' ranu iwure 'the water foamy' } \\
& i-+ \text { wara 'tell' } \rightarrow \text { iwara 'tell' } \quad \text { Here iwara paadu 'they tell the wedding }
\end{aligned}
$$


The i- as reflected in the data below, does not give or change the meaning of base forms embedded. Its appearance in these words does have any meaning, and it used to make it different from its use in daily language.

(1) Iya itaretek rawen angang

(2) Inyampuran ku rawen tewu

(3) Itarabe lawi tampun

(4) Iwaruga $k u$ talanyaan

(5) Inapunsu seni tari

(6) Ia itarawen upi

(7) Pampalusan itawila uei 'children cut the angang leaves'

'I mix it with sugar cane leaves'

'the tip of tampun leaves swaying'

'I come to dancing place'

'preserving the art of dancing'

'children looking for taro'

'all looking for rattan blades

It is similar to the clitics form $-n i$. Clitics are a dependent form that phonologically has its stress and cannot be considered as dependent morpheme because it can fill the gap at the phrase or clause levels but has no characteristics of the word because it cannot be used independently (Kridalaksana, 2008). Clitics -ni in the DM language includes the third pronoun and is probably embedded to base nouns, verbs, and adjectives. If it is embedded to base nouns and adjectives, it functions as possessor. For example,

$$
\text { Itak 'nenek'+-ni } \rightarrow \text { itakni 'neneknya' itakni wigas 'neneknya sehat' }
$$

The clitic $-n i$, as reflected in the data below from (8) to (13) are unusual, in which its usage is slightly excessive compared to its usage in the daily language. They do not give or change the meaning of base forms embedded. Its appearance in these words does have any meaning, and it used to make it different from its use in daily.

(8) Siang wakai-ni balule

(9) Rearere rawen-ni katila

(10) Inyampuran rawen-ni Kananga

(11) Tumang kakau-ni Palawan

(12) Pampalusan midi-ni la'uah

(13) Minau pakan ni Mangkarap

$$
\begin{aligned}
& \text { 'squash root swinging' } \\
& \text { 'papaya leaves swinging' } \\
& \text { 'mixed with ylang leaves' } \\
& \text { 'Palawan tree fallen' } \\
& \text { 'as well as buying galangal' } \\
& \text { 'going to Mangkarap market' }
\end{aligned}
$$

Besides, there is the use of particle sa. The word sa refers to 'that,' but may also function as a confirming particle. For example, Yina sa dukterni 'This is the dokter?'. However, particle sa used in Riak utterances as represented from data (14) to (17) below means nothing.

(14) Palit ira sa tangukaran

(15) Arai atei takam tau sa pangasungu

(16) Tulak ia sa ngalap watu

(17) Pampalusan midi ni sa la'uah 'greasing the tangkuraran blood'

'happy to meet you all' 'children going to take stones' 'as well as buying galangal'

The three forms of the word usage in Riak with specific morphological characteristics, such as affix -i, clitics $n i-$, and particle $s a$ indicate the use of language form to show the beauty of call sound. In the DM community, riak in each traditional ritual is always uttered by wadian with a certain rhythm using the different morphological forms with its usage in the daily life, so that makes the rhythm of riak sound beautifully. 
Following that, Riak also uses specific language styles like repetition in sound and words. This repetition creates the effect of softness, sharpness, or beauty of the sound to make it sound beautiful. The use of these language styles also distinguish it from everyday language, and it emphasizes the harmony of sound so that it is more pleasant to hear.

There is assonance in Riak, the repetition of the same vowel sounds in consecutive words.

(18) Rearare sa rawen angang

(19) Wurung walatik makan walatih

'angang leaves swinging'

'the wren eat walatih'

The assonance of sound from Riak above can be seen ni a - a vowel sound in rearare sa rawen angang (from data 18) and walatik makan walatih (from data 19). There are also $\mathrm{i}$ - i vowel sound in walatik walatih in data (19).

There are also alliteration, the repetition of the same sounds, or the same kinds of sounds at the beginning of words or in stressed syllables (Shapiro, 2017). The alliteration in Riak can be seen in consonant sounds at the beginning of each word from data (20) below.

(20) Tetung telu sa tetung telu 'Three hedgehogs'

Moreover, there are also anaphora, the deliberate repetition of a word or phrase at the beginning of several successive verses, clauses, or paragraphs (Shapiro, 2017). Repeated forms of words are in bold as seen in data (21) to (23) below

(21) Warik nuping, warik nuping 'the monkey jump'

(22) Tuu maeh sa tuu maeh 'really good'

(23) Midi ete sa midi ete 'buy dedak'

Forms of language with the specificity of the words and language style used in the Riak, as mentioned above, are different from their use in everyday language. These forms show its function, which is used in ceremonial or religious activities in the DM community. Description of language in this context is closely related to the Pangunraun language, the language used in traditional rituals in the DM community. This language variety is used by Wadian, known as a sacred language, because it is used in Wadian songs, exclamations, or utterances to connect between humans and divinity.

In Riak, there are also words describing the natural wealth of the DM community. Riak appears spontaneously during the ritual. It often contains various kinds of plants, animals, traditions, or habits in the daily life of the DM community. From data (24) to (28), various kinds of plant uttered are significant in the DM community life, such as the following.

(24) Rearere sa rawen angang, 'angang leaves swinging' inyampuran ni pusuk katu 'mixed with tip of katuk leaves'

(25) Ni Papuan raga-raga

'papuan fruits are big'

anak upis sa ngaun salai 'anak upis bring the smoked'

(26) Ia itarawen upi 'children looking for taro' pampalusan itawila ue'i

'all looking for rattan blades' 


\author{
Nitarabe lawi tampun \\ Surung tabe kain deu dile \\ Sanali sa tadi keang \\ umak nuruk jamatan tetei
}

Rawen angang (24) 'fiddlehead green' is a kind of coarse grass growing in peatlands, in which its root is often used as medicine. Pusuk katu (24) 'tip of katuk leaf', usually grows in the agricultural field or surrounding house. Papuan (25) 'Papuan fruit' is one of the typical fruits that only grows in Kalimantan, having small and orange seeds, sweet taste, and usually eaten with its seed. Salai (25) is 'dried fruits' in which if fruit season comes, fruits are plentitude. The DM community habitually pickle fruits by drying it in the sun to avoid waste and to have it lasted long. Uei (26) 'rattan' is used as materials of life equipment, such as mat, bag, chair, and so forth. Even a young rattan is cooked as a side dish (vegetable). It indicates that rattan has many roles in the daily life of the DM community. Upi (26) 'caladium', caladium plant mostly grows in the residential area of the DM community. Its tuber and spiraling are used as a side dish (vegetable), stem and leaf are usually cooked for feeding pig, so there are no useless parts of this caladium. Lawi tampun (27) 'tip of Chinese water chestnut leaf', Chinese water chestnut is weeds in peatlands or swamp field. In the surrounding residential area of the DM community, there is a swamp filed where this Chinese water chestnut excessively grows. The DM community utilizes it by making a mat and bag from this plant. The mat made from this tip of Chinese water chestnut leaf is used as a cushion in the traditional ceremony. Keang (28) is the name of a plant in which its barks can be processed to be a solid rope.

Moreover, it can be used to tie a bridge. Its fiber is also used for clothing materials. DM community often use those plants (in data 24-28) in their daily life dan along with the spontaneously of riak, those words connected with the plants around them reflected.

\subsection{The Cultural Meaning in Riak}

As noted by Rais (2017), the goal of ethnolinguistic research to find out and investigate the meaning behind using language to get cultural understanding, which starts from language facts. This subchapter will discuss the cultural meaning reflected in Riak. Sharifian (2012) views culture as a system of collective beliefs, worldviews, customs, traditions, values, and norms shared by members of cultural groups. These can be reflected in the words, phrases, and utterances used in Riak.

Words and phrases meaning used in Riak reveal the tradition of living in the DM community. Data (29) and (30) indicate the use of phrases reflecting the DM community culture.

(29) Minau pakan ku ma Ampah 'going to Ampah Market'

(30) Mamai kami ma balai natat 'we come into the house'

The DM community culture is reflected by the meaning of phrase minau pakan 'going to market'. Pakan day means market day in East Barito district only occurs once in a week in each village by turns. On this day, the DM community usually does not carry out any regular activities or jobs but will go to the market to buy various living needs that cannot be found in nature. This market day is also utilized to 
convey information or invitation of a particular event to siblings or colleagues. In a specific season, such as fruit season, this market day is also utilized by some DM community who live in villages and have many orchards to sell their fruit crops. Hence, the market will be very crowded, visited by many people. Therefore, minau pakan or going to market at market day becomes essential for the DM community. The use of word minau 'going down' in Riak utterance in data (29) does not means going down from the top of something to the lower one, but in the DM community culture, that word means going out from the house to a particular place. The use of this word relates to the tradition in the DM community who live in the house built highly from the land or so-called rumah panggung or lewu hante in DM language. Hence, the word minau 'going down' is used to state 'going out of the house'. Conversely, mamai 'going up' has the cultural meaning 'coming into the house' as shown in data (30).

Phrases to address people in the genetic relationship system of the DM community is also reflected in riak as the following data

(31) Itak kakah, ineh ambah, tutu mama, pangulu mantir uras baharap 'nenek kakek, mother father, aunty uncle, cultural leader, are hoping'

In the DM community tradition and culture, women play quite essential roles. The master of ceremonies concerning tradition and religion is usually a woman. In the DM community, women can have an equal position with a man. Moreover, in some contexts (i.e., traditional ceremony), women have a higher position than men. These traditions and cultures are also represented in language use, such as in phrases to address the genetic relationship system. The position of women is always stated first, such as itak kakah 'nenek kakek', ineh ambah 'mother father', and tutu mama 'uncle aunt' (31).

Riak utterances also contain some types of animals that become a typical characteristic of the DM community, such as the following.

(32) nyunrut mansi pitenungan 'to see the forecasting bird'

(33) nampalus adat iwurung jue 'implementing the wurung jue custom'

Data (32) and (33) show two types of animals actively give a contribution to the DM community life, particularly in the traditional ceremony. Mansi (32) is a bird used as a sign or used to predict an event. This bird is believed can give a sign or answer for questions asked by Wadian. Wurung Jue (33) 'Bornean Peacock-Pheasant' usually lives in the mountain area in Barito. This bird is the most challenging kind to be found and to be caught alive since it needs a particular trick. According to the DM community, Wurung Jue means a sign of self-faithfulness, chastity, majesty, pureness, and vigilance from threats. It has a faithful characteristic to its spouse. If its spouse dies, it will die too. Consequently, wadian iwurung jue dance is performed in the ceremony of fulfilling the customary law of DM marriage. Prefix $i$ - in wurung means 'like', so iwurung jue phrase means 'like a Bornean Peacock-Pheasant' that's means with the hope and believe that the bride and groom who marry by DM ritual tradition will be faithful till death like the Bornean Peacock-Pheasant. 
In DM culture, identity is essential. When someone wants to speak in a meeting forum, he or she has to introduce himself. Usually, they start with their name, and then they will mention the origin of his descendants or his family. Their famous ancestors will be mentioned, as well. For example,

Ngaranku hi Dime, aku na anak amah Isa umpu Pa' Idei sa tukang ngulah mandau sadi 'My name is Dime, I am the son of Isa's father, the grandson of Idei's father, the mandau maker.

For Wadians who lead the ritual in the traditional wedding ceremony, showing their identity is also a must.

(34) Kami Wadian sa ngurai tanya 'We are Wadian who will ask'

(35) Ina kami anak kesenian, inapunsu seni tari 'This us, preserving dance art'

The two Riak above reveal the meaning that even Wadian, before doing their actions, first introduce themselves by calling their identities as Wadian. Data from (88) implies their true identity that they are not real Wadian.

\section{Conclusion}

Riak in the DM community, now, can be recognized in the traditional wedding ceremonies conducted by wadian. Each Riak mostly consists of four lines, in which the first two lines aim to prepare rhyme and rhythm to ease audiences' understanding. These first two lines, in the beginning, are an illustration of the culture and the natural or environmental conditions in which the DM community lives. The second two lines are the purpose or content of Riak that reveal the purpose of the Wadian in the ceremony.

Some forms of word use in riak are morphologically different from its usages in the daily DM language, such as the use of affix i-, clitic -ni, and particle sa. Riak also applies in specific language styles, such as repetition like assonance, alliteration, and anaphora. Those differences are to give a sense of beauty to Riak's utterances. The use of these differences creates the effect of softness, sharpness, and beauty to make it sound beautiful. These are used to distinguish it from everyday language because the language used by Wadian is known as a sacred language to connect humans and divinity.

Regarding the use of words, phrases, and sentences in Riak utterances, some meanings show DM community culture. The meaning of minau that culturally means going out of the house, and mamai means 'coming into the house'. The phrase ineh ammah 'mother father' or itak kakah 'grandma grandpa' that always said with the woman side first, instead of the man. This phrase arrangement word means that in DM Community woman has a unique position. There also some words connected with the name of a particular bird in the DM community that has a unique meaning in DM tradition. Sentences that show particular norms in the DM community also found in Riak. Accordingly, through the meaning of those words, phrases, and sentences, the cultural understanding of the DM community reflected. These are clarified that the community culture can affect language meaning. 


\section{References}

Arini, D. N. (2016). Politeness Distinction: Terms of Address Used By Banjerese Youth In Daily Life. Langkawi, 2(2), 233--248.

Blust, R. (2015). The Austronesian Languages (Revised Ed). Canberra: Asia-Pacific Linguistics Research School of Pacific and Asian Studies The Australian National University.

Copland, F., \& Creese, A. (2015). Linguistic Ethnography. London: Sage Publications.

Crystal, D. (2008). A Dictionary of Linguistics and Phonetics (6th ed.). Oxford: Blackwell Publishing.

Duranti, A. (1997). Linguistics Anthropology. Cambridge: Cambridge University Press.

Eberhard, D. M., Simons, G. F., \& Fennig, C. D. (2019). Ethnologue: Languages of the World. Twenty-second edition. Dallas, Texas: SIL International. Retrieved from http:/ / www.ethnologue.com

Foley, W. A. (2016). Anthropological Linguistics and Field Linguistics. In K. Allan (Ed.), The Routledge Handbook of Linguistics (pp. 250-263). London and New York: Routledge, Taylor and Francis Group.

Fox, J. J. (2014). Explorations in Semantic Parallelism. Canberra: ANU Press.

Gunawan, F. (2005). Analisis Komponen Makna Unta Berdasarkan Penyakit Dalam Bahasa Arab. Jurnal Adabiyyat, 4(1).

Herrmans, I. (2015). Rituals Retellings, Luangan Healing Performances through Practice. New York, Oxford: Berghahn.

Herrmans, I. (2017). Values in Practice: Change and Continuity in Luangan Ritual Performance. In C. Arenz, M. Haug, S. Seitz, \& O. Venz (Eds.), Continuity under Change in Dayak Societies (Sozioökono, pp. 191-214). Wiesbaden: Springer VS. https:// doi.org/10.1007/978-3-658-18295-3

Kridalaksana, H. (2008). Kamus Linguistik Edisi Keempat. Jakarta: Gramedia Pustaka Utama.

Mage, A. M. (2014). Semantic Analysis of Ethnopoetics of Pangunraun In Mariage Negotiations of Maanyan Dayak of Central Kalimantan. The Multifaceted Dimensions of English Linguistics, Literature, and Education, 343-363.

Rais, W. A. (2017). Kearifan Lokal dalam Bahasa dan Budaya Jawa: Studi Kasus Masyarakat Nelayan di Pesisir Selatan Kebumen Jawa Tengah (Kajian Etnolinguistik). Surakarta: UNS Press.

Riswara, Y. (2012). Puitika alam Lirik Saluang: Sebuah Kajian Etnolinguistik Minangkabau. Madah, 3(2), 113-121.

Rodriguez, L., \& Lopez, S. D. (2019). Performing Healing: Repetition, Frequency, and Meaning Response in a Chol Maya Ritual. Anthropology of Consciousness, 30(1), 42-63. https:/ / doi.org/10.1111/anoc.12107

Saville-Troike, M. (2003). The Ethnography of Communication: An Introduction (3rd Ed.). 
Malden; Oxford; Melbourne: Blackwell Publishing Ltd.

Shapiro, M. (2017). The Speaking Self: Language Lore and English Usage. Cham: Springer International Publishing AG.

Sharifian, F. (2012). Cultural Linguistics. In C. A. Chapelle (Ed.), The Encyclopedia of Applied Linguistics (pp. 1-6). Oxford, UK: Blackwell Publishing Ltd. https:// doi.org/10.1002/9781405198431.wbeal0299

Sharifian, F. (2014). The Routledge Handbook of Language and Culture. New York, NY: Routledge.

Soriente, A., \& Inagaki, K. (2012). Kalimantan languages: An overview of current research and documentation. In Current Trends of Linguistic Research of Indigenous Languages in Indonesia. Retrieved from https://lingdy.aa-ken.jp/wpcontent/uploads/2012/01/120217_soriente_inagaki_h2.pdf

Suhandano. (2004). Klasifikasi Tumbuh-Tumbuhan dalam Bahasa Jawa: Sebuah Kajian Linguistik Antropologis. Disertasi. Universitas Gadjah Mada.

Sumadi, Septiana, D., \& Yuliadi. (2015). Bahasa Maanyan, Lawangan, Bakumpai, Paku: Sebuah Penelitian Kekerabatan Bahasa di Kabupaten Barito Timur, Kalimantan Tengah. Yogyakarta: Lokus.

Ukur, F. (1971). Tantang-Djawab Suku Dayak: Suatu Penyelidikan tentang Unsur-unsur yang Menyekitari Penolakan dan Penerimaan Injil di Kalangan Suku Dayak dalam Rangka Sejarah Gereja di Kalimantan 1835-1945. Jakarta: BPK Gunung Mulia.

Wardhaugh, R., \& Fuller, J. M. (2015). An Introduction to Sociolinguistics (7th ed.). Malden; Oxford; West Sussex: Wiley Blackwell.

Wheelock, W. T. (1982). The Problem of Ritual Language: From Information to Situation. Journal of the American Academy of Religion, 50(1), 49-71. 